Jurnal Ilmu Sosial dan Pendidikan (JISIP)

Vol. 5 No. 3 Juli 2021

Terakreditasi Peringkat 5 (No. SK: 85/M/KPT/2020)

e-ISSN : 2656-6753, p-ISSN : 2598-9944

DOI: 10.36312/jisip.v5i3.2142 /http://ejournal.mandalanursa.org/index.php/JISIP/index

\title{
Globalisasi Budaya Bagi Mahasiswa Indigenous Papua Di Arus Perkembangan Kota
}

\author{
Lewi Kabanga \\ ${ }^{1}$ Sastra Inggris, Universitas Sains dan Teknologi Jayapura \\ Email: lewikaban@gmail.com
}

\begin{tabular}{l}
\hline \hline Article Info \\
Article history: \\
Article Accepted: 22 June 2021 \\
Publication : 11 July 2021 \\
\\
Keywords: \\
Language, Cultural Globalization, \\
City, Indigenous Students, Papua, \\
Inter-Racial Marriage
\end{tabular}

Inter-Racial Marriage

$\overline{\text { Article Info }}$

Article history:

Article Accepted: 22 Juni 2021

Publication : 11 July 2021

\section{Keywords:}

Bahasa, Globalisasi Budaya, Kota, Mahasiswa Indigenous, Papua, Pernikahan antar Ras

\begin{abstract}
The nature of globalization is breaking through the geographical boundaries of area and changing the forms that have been established before. Cultural globalization seems to create new culture. The purpose of this research is to give description about the existence of Globalization in language and inter-racial marriage in Jayapura. This research used descriptive qualitative method. The object of this research was the indigenous students of Papua in Jayapura. Places to obtain the data were in student's dorms such as Biak, Fak-fak, Wamena and Meraukes's dorms. Focus Group Discussion (FGD) was the single manner in collecting data. This technique applied semi-structured way in which the researcher developed and dig elaborately the questions to find the core answers. Recording was the way documented FGD. Recorded data was transcribed and then reduced by classifying and indexing features of globalization in language and interracial marriage. The findings were analyzed and described based on contextual phenomenon. The result of this research revealed that (1) language phenomenon was in cost and benefit of practical used, they tended to "code mix" in order to broad the scope area of their communication, moreover with this term their social relation could be run effectively. (2) inter-racial marriage responds were caused by both internal and external factors that indicated the attitude to face the similar case

Abstrak

Sifat dari globalisasi adalah menerobos batas geografis wilayah dan mengubah tatanan yang sudah terbentuk sebelumnya. globalisasi budaya cenderung menciptakan budaya baru. Tujuan penelitian ini adalah memberikan deskripsi mengenai eksistensi globalisasi bahasa dan pernikahan antar ras di Jayapura. Metode yang diguanakan adalah metode deskripsi kualitatif. Objek penelitian adalah mahasiswa/i indigenous Papua di kota jayapura. Lokasi pengambilan data adalah asrama mahasiswa seperti asrma Biak, FakFak, Wamena, dan Merauke. Focus Group Discussion (FGD) adalah cara yang digunakan dalam megumpulkan data. Teknik ini menerpakan semi terstruktur dimana peneliti mengemabangkan dan menggali pertanyaan untuk mendapatkan wacana jawaban inti yang dibutuhkan. Teknik rekam adalah cara mendokumentasikan data dari FGD. Data yang direkam kemudian ditranskrip dan direduksi dengan cara mengklasifikasi dan mengindeks alasan fitur penentu globalisasi bahasa dan pernikahan antar ras. Hasil temuan tersebut dianalisa dan dideskripsikan berdasarkan kontektualisasi fenomena nyata yang terjadi di lapangan. Hasil menunjukkan bahwa (1) fenomena bahasa berada pada cost dan benefit yaitu mereka harus mencampur kode bahasa untuk memperluas ruang lingkup berkomunikasi selain itu "campur kode" menunjukkan adanya relasi sosial mereka dapat terjalin dengan baik. (2) Respon pernikahan antar ras berupa pengaruh faktor internal dan eksternal yang menandakan adanya kesiapan dan ketidak siapan jika menghadapi kasus yang serupa.
\end{abstract}

This is an open access article under the Lisensi Creative Commons Atribusi-BerbagiSerupa 4.0 Internasiona

\section{Corresponding Author:}

Lewi Kabanga

Sastra Inggris, Universitas Sains dan Teknologi

Jayapura

Email: lewikaban@gmail.com

\section{PENDAHULUAN}

Pada awalnya globalisasi muncul dari penyebaran budaya barat yaitu perjalanan bangsa Eropa dalam menjelajahi dunia. Akan tetapi istilah globalisasi berkembang pada abad ke-20 yaitu dengan adanya perkembangnya teknologi informasi dan komunikasi. Adanya perubahan 
kontak fisik menjadi kontak media sebagai sarana yang utama. Hal ini membuat perubahan pada bidang komunikasi berubah secara praktis dan efisien.

Secara umum globalisasi adalah perubuhan yang terjadi secara universal. Perubahan yang terjadi adalah proses transformasi pengembangan ke arah sistem-sistem global. Dalam hal ini perubahan yang terjadi di suatu negara bisa berdampak atau diikuti di negara lain. Giddens (2001) mengatakan bahwa globalisasi merupakan intensifikasi hubungan sosial dunia. Globalisasi menuntut suatu negera untuk membuka diri terhadap perkembangan khususnya pada perkembangan ekonomi suspaya dapat bersaing dan saling melengkapi. Sehingga, globalisasi merupakan perubahan yang dibawah oleh suatu wilayah dan berpengaruh ke wilayah lain yang bersifat gloabal.

Belum ada defenisi pasti mengenai globalisasi, theorist hanya menggambarkan secara defenitif mengenai akar kata dari globalisasi yaitu "universal atau menyeluruh. Gambaran globalisasi hanya dilihat dari defenisi kerjanya yang artinya defenisi globalisasi dapat dilihat dari sudat pandang tertentu. Perubahan yang terjadi dapat dilihat dari sudut pandang atau proses sosial, agama, kultur, ekonomi, dan proses alamiah yang berdampak kepada perubahan besar di mana suatu negara saling bergantung satu dengan yang lainnya.

Robertson dalam Surahman (2013) memberikan konsep globalisasi sebagai penyempitan dunia secara insentif dan merangsang pemahaman kita mengenai dunia. Hal yang senada juga disampaikan oleh Barker, dalam surahman 2013, bahwa globalisasi merupakan koneksi pada bidang ekonomi, sosial, budaya, dan politik. Koneksi tersebut bersifat global, yang mengarah ke seluruh dunia dan mempengaruhi kesadaran kita.

Ada 2 hal yang ditekankan Robert mengenai konsep globalisasi yaitu penyempitan dunia dan pemahaman akan dunia. Penyempitan dunia adalah kontektualisasi dari perkembangan dunia dalam hal modernisasi sedangkan pemahaman dunia adalah pandangan terhadap budaya yang akan semakin membaik. Pada sisi lain, budaya adalah warisan mulia yang harus dipertahankan karena budaya merupakan hasil karya, cipta, dan rasa manusia. Dikatakan karya karena manusia menghasilkan benda atau wujud yang bisa dimanfaatkan setiap hari. Cipta adalah kemampuan manusia secara mental untuk berpikir dan menghasilkan ilmu pengetahuan. Rasa adalah semua unsur expresif manusia dalam melahirkan norma, hukum, agama, dan ideologi (Donny, 2017). E.B Taylor (1887) mendefenisikan budaya sebagai semua hal-hal yang melingkupi semua pengalaman Manusia. Jadi budaya adalah produk yang diciptakan manusia. Rendel (2010) memberikan informasi bahwa budaya dapat ditransformasikan melalui interaksi langsung atau tidak langsung dalam bentuk proses belajar. Dalam hal ini budaya tidak dilahirkan secara genetik tetapi budaya ditransfer melalui proses akultrasi atau proses interaksi dimana manusia belajar menerima budayanya.

Papua adalah salah satu wilayah atau provinsi yang terletak di ujung timur Indonesia. Papua merupakan ras melanesia. Penyebaran ras melenesia secara regional adalah sepanjang pasifik selatan. Di Indonesia, ras ini menyebar di Papua, Papua barat, Maluku dan NTT. Di Papua tercatat bahwa ada 255 suku dengan bahasa yang masing-masing berbeda. Pada umumnya kehidupan sosial di Papua adalah kolektif dan memegang asas kekeluargaan dan kebersamaan. Masyarakat Papua sangat menghargai kepala suku dan orang yang lebih tua dari dirinya. Itu membuktikan bahwa masyarakat Papua respek atau menaruh rasa hormat terhadap pemimpin mereka. Papua mempunyai bentuk topografi yang kompleks. Hal ini yang membuat pembungan di Papua mengalami kelambatan. Namun sangat berbeda dengan Kota Jayapura. kota ini mengalami pembangunan fisik yang berbeda dengan daerah-daerah lainnya di Papua.

Di tengah perkembangan kota, Masyarakat dan arus modernisasi yang begitu cepat. Masyakat Papua mengalami cultural shock atau guncangan budaya. Jayapura adalah salah satu kota transmigrasi yang ada di Indonesia karena hampir semua suku bangsa di Indonesia ada di Jayapura. Arus mobilasasi pendukuk ke Papua terjadi sejak pemerintahan orde baru. Tujuannya adalah Papua adalah daerah yang luas sehingga untuk memeratakan kepedatan penduduk khususnya di daerah Jawa maka beberapa daerah di Indonesia termasuk Papua adalah derah 
tujuan transmigrasi. Selain daerah tujuan transmigrasi, arus mobalisasi penduduk ke Papua didasari atas pencarian lapangan kerja dan dasar ekonomi.

Dengan adanya penyebaran dan mobalisasi penduduk ke Papua, khususnya ke Jayapura, tidak terlapas dari adanya pembauran budaya antara penduduk asli Papua dengan pendatang. Melirik fungsi dari kota, karena Jayapura adalah salah satu kota yang berkembang yang pesat di Indonesia, bahwa kota merupakan pusat atau sentralisasi dari segala sektor pembangunan. Kota merupakan pusat ekonomi, kesehatan, informasi dan komunikasi, dan Pendidikan. Masyarakat dapat mendapatkan informasi, pelayanan kesehatan dan Pendidikan di kota. Oleh sebabnya itu, kota adalah cermin akultrasi budaya karena tidak tertutup kemungkinan orang akan berbondong ke kota untuk mendapatkan tujuannya dari fungsi kota tersebut. Sujarto, 1989, (dalam Hanifa) Berpendapat bahwa ada 3 faktor yang mempengaruhi perkembangan kota yaitu (1) faktor penduduk yang menyangkut kelahiran dan migrasi, (2) faktor kegiatan manusia yaitu segi kegiatan kerja, fungsional, perekonomian, dan kegiatan regional yang lebih luas, dan (3) faktor pergerakan yaitu perkembangan kota yang dipegaruhi oleh kedua faktor di atas yang membentuk pola dan pusat-pusat kegiatan.

Perkembangan kota tidak lepas dari arus globalisasi yang membawa pengaruh dan menawarkan perubahan dan benefit tertentu. Globalisasi tidak mengenal batas wilayah dan dapat menerobos benteng atau akar yang kuat yang sudah dibangun dan ditanam sebelumnya. Lagipula, globalisasi akan mengubah tatanan atau struktur atau komponen budaya yang sudah ditetapkan. Komponen budaya adalah unsur-unsur tertentu yang mengatur tatanan hidup bermasyarakat. Ada 7 komponen atau unsur budaya, mereka adalah adat istiadat, religi, artefak, bahasa, teknologi, dan norma-norma. Sejalan dengan Anakotta (2019) mengatakan bahwa budaya adalah sistem yang mencakup setidaknya ada bahasa, kepercayaan, benda musik, dan aktivitas masyarakat yang mempunyai fungsi dan saling berkaitan satu dengan yang lainnya.

Uniknya di Papua terdapat kurang lebih 255 suku itu mengimplikasikan bahwa kurang lebih ada 255 bahasa yang eksis di Papua. Dengan adanya globalisasi maka bahasa juga akan mengalami perubahan karena pengaruh fungsi dari bahasa yang mengglobal menggeser bahasa lokal. Fungsi dari bahasa adalah sebagai alat komunikasi atau interaksi untuk menyampaikan infomasi, tujuan dan maksud dari pembicara ke pendengar. Muysken berpendapat bahwa bahasa berubah karena reaksi sebab-akibat terhadap perubahan lingkungan. Graddol (2004) menambahkan bahwa perubahan bahasa dipengaruhi oleh beberapa faktor seperti perkembangan kota, pertumbuhan penduduk, perkembangan ekonomi dan perkembangan globalisasi.

Bahasa sebagai alat komunikasi akan menjadi mediasi antara masyarakat yang sudah berbaur, masyarakat asli Papua dan masyrakat Imigran. Pembauran itu tidak kalah pentingnya dari selektivitas bahasa yang digunakan yang melibatkan konteks situasi, di mana dan kapan interaksi itu terjadi. Selain itu, media teknologi mempunyai peranan penting dari perkembangan bahasa. Instruksi penggunaan bahan dan alat teknologi serta makanan terkadang dilebelkan dalam bahasa yang berpower. Media informasi dan komunikasi mendorong globalisasi budaya mengalir lebih cepat. Oleh sebabnya itu, bagaimana ekisitensi bahasa lokal Papua setelah berada di kota jayapura adalah salah satu indikator yang akan mewarnai penulisan ini.

Kehidupan di kota juga terlepas dari selera dan gaya hidup. Dalam hal ini, selera adalah pilihan hati yang bersifat mutlak. Hidup di kota memberikan pilihan hidup yang bervariatif. Menurut Wahyuni dan Bonowati (2016) yang melakukan penelitian tentang gaya hidup remaja kelas menengah di pekalongan berpendapat bahwa perubahan gaya hidup mengakibatkan berubahnya pola pergaulan. Pertemuan dari berbagai suku bangsa di Jayapura membuat kota ini seakan-akan merupakan melting pot yang menampung semua budaya suka bangsa dan menjadikan budaya luar itu menjadi budaya daerah itu. Tidak terlepas dari perpaduan budaya di kota Jayapura, perkawinan antar suka bangsa atau inter racial marriage tidak akan terelakkan juga. Perkawinan tersebut akan memadukan dua budaya yang berbeda. Menurut Matsumoto dan Juang (dalam Imanda dan Masykur, 2016) mengatakan bahwa dalam pernikahan antar budaya, dimana pasangan yang berasal dari dua latar belakang budaya yang berbeda. perbedaan buday 
terdapat pada perbedaan perilaku dan pandangan mengenai cinta, ketertarikan interpersonal, dan pernikahan.

penelitian ini akan memberikan jawaban yang bersifat asumtif dan reasonnable mengenai penerimaan pernikahan antar ras yang terjadi di Jayapura sebagai kota yang majemuk dan convergence.

Pentingya penelitian ini akan memberikan gambar mengenai eksistensi dan perkembangan bahasa di Jayapura di tengah arus globalisasi. Selain itu, penelitian ini juga memberikan pandangan akan sikap penduduk indigenous people Papua, khususnya mahasiswa, mengenai pernikahan interracial marriage yang sudah dan sementara berlangsung di kota Jayapura. Kedua kiat ini adalah bagian dari unsur-unsur budaya yang tergeser dari arus globalisasi. sehingga penelitian ini akan membawa pola pikir mengenai pandangan generasi milenial Papua sekarang ini mengenai bahasa lokal mereka dan pernikahan antar ras yang tarus terjadi melaui relasi sosial antar migran di Jayapura.

Tillar dalam Uno dan Nina (2014) menjelaskan bahwa tulang pungung dari globalisasi adalah bisnis dan teknologi. Hal ini didukung dari ide bahwa globalisasi memasuki 3 rana penting kehidupan manusia. Ketiga rana itu adalah ekonomi, politik, dan budaya sehingga terbentuklah kekuatan yang menjadi punggung dan vasilitator dari globalisasi. Budaya yang mempunyai pengaruh yang kuat akan menyebar dengan pesatnya ke wilayah lain. Istilah westernisasi adalah suatu dominasi wilayah-wilayah barat dalam menyebarkan budaya-budaya mereka. Sehingga westernisasi adalah suatu istilah konteks budaya yang disebarkan dari negara barat dan diadopsi dan diikuti oleh negara lain. Larasati (2018) berpendapat bahwa westernisasi adalah suatu produk dari globalisasi. dia manambhkan bahwa globalisasi terjadi tidak hanya bidang ekonomi dan politik tetapi juga terjadi pada aspek-aspek lain termasuk pada bidang budaya dan kemudian menghasilkan budaya baru yang disebut hybrid budaya.

Globalisasi mengubah sistem budaya yang bersifat heterogen menjadi homogen. Istilah homogenitas budaya juga tidak lepas dari istilah kapitalisme. Budaya barat yang mengglobal terus menerobos batas geografis negara melalui ideologi kapitalisme. Dalam hal ini, globalisasi kapitalisme menghilangkan keberagaman. Robbin dalam Sholahuddin (2019) menjelaskan bagiamana tradisi masyarakat lokal yang bersifat heterogen dalam kehidupan yang bersifat global. Ia manambahkan bahwa budaya yang bersifat dominan akan menggeser budaya lokal dan terus membesar bersama dengan perkembangan informasi dan media massa. Imperialisme suatu budaya akan mengakibatkan budaya lain akan terpengaruh bahkan terhapus dari permukaan peradapan dunia. Sejalan dengan Yulianto (2007) mengtakan bahwa modernisasi dan globalisasi membentuk masyarakat semakin homogen. Dia juga menambahkan bahwa globalisasi membentuk suatu sistem standarnisasi melalui teknologi sehingga nilai budaya lokal yang dulunya eksis berubah menjadi nilai-nilai yang modern.

Ada 3 hal yang bisa membuat penetrasi budaya asing membentuk budaya yang homogen. Globalisasi, kapitalisme, dan konsumerisme adalah homogenitas budaya yang menyatakan bahwa cepat atau lambat keanekaragaman sebagai budaya asli suatu daerah akan mengakibatkan hilangya heterogenisasi budaya. Perilaku yang konsumtif adalah perilaku yang diciptkan oleh masyarakat untuk terus dan terus menerima dan menjadikan sesuatu yang asing menjadi milik dan merupakan bagian dari sendiri. Hal ini yang membuat nilai aset lokal akan terus tersudutkan dan mengakibatkan adanya erosi dari budaya itu sendiri yaitu suatu pengikisan budaya dimana tanpa sadar masyarakat lokal yang membuat budaya milik sendiri hilang dan terhapus.

Globalisasi budaya dalam konteks meluas sudah mempengaruhi nilai-nilai moral, sosial budaya, cara berfikir dan gaya hidup. Pola hidup yang berkelompok berubah menjadi individual, nilai moral dan kearifan lokal berubah menjadi nilai yang salalu dilandaskan pada nilai ekonomis dan faedah. Perubahan terus mewabah sebagai virus global budaya yang terus mempengaruhi sendi kehidupan masyarakat. Oleh sebabnya itu kesiapan adalah mental utama yang harus disiapkan sebagai perisai untuk memfilter virus budaya asing yang terus menusuk dan merusuk sel-sel budaya lokal. Perlu adanya ketahanan budaya lokal dalam menciptkan jati 
diri bangsa/masyarakat. Ni Komang Ayu Astiti (2018) berpendapat bahwa Artefak adalah sumber historis budaya lokal yang mempunyai daya tarik dan perlu dipertahankan dan dilestarikan karena artefak dapat meningkatakan ketahanan budaya di era globalisasi saat ini. Selian itu artefak juga bisa memberikan manfaat yang secara emotional dan ekonomis yang tinggi.

Globalisasi dan budaya adalah hal yang saling mempengaruhi karena di dalam globalisasi ada hal yang terbaru dari luar menyelip masuk kedalam budaya. Perpaduan itu membuat atau melahirkan/hybrid budaya baru dan lama saling berjalan beriringan. Annakotta, Alman, dan Solehun (2019) melakukan penelitian tentang akultrasi yang terjadi dalam masyarakat di Papua barat dan imigran. Tujuan penelitian mereka adalah menginvesitgasi bentuk-bentuk akultrasi yang terjadi dalam masyarakat dan bagaimana akultrasi tersebut mempengaruhi masyarakat. Hasil penelitian mereka menunjukkan bahwa perbedaan sosial yang ada menjadi gap terbentuknya akultrasi terhadap budaya mereka. Namun demikaian akultrasi tetap terjadi dalam masyarakat secara lamban. Bentuk akultrasi yang terjadi dalam masyarakat di Papua barat dan imigran adalah subsitusi, sinkretisme, adisi, dekultrasi, originasi, dan penolakan. Dampak dari akultrasi tersebut tidaklah terlalu merugikan masyarakat akan tetapi adanya budaya yang berbeda saling berdampingan. Dampak lain adalah adanya kebudayaan yang lahir karena karena berlandaskan kesepakatan, semakin kuatnya apresiasi yang ditandai dengan kekerabatan, kebersamaan, dan sifat saling tolong menolong.

Globalisasi juga merambah ke dalam dunia pendidikan. Indriyani dan Agustinah (2019) melihat dampak globalisasi dalam dunia pendidikan. Penelitian mereka melihat perilaku belajar siswa SMK Negeri 1 Cianjur di tengah pesatnya perkembangan globalisasi. Hasil penilitian mereka menunjukkan bahwa globalisasi secara nyata berdampak terhadap perilaku belajar siswa. Dampak tersebut dapat berpengaruh langsung terhadap kepekaan belajar, motivasi belajar, sikap dan moral, dan keaktifan belajar siswa-siswi SMK I Cianjur.

Sholahuddin (2019) meneliti glibalisasi sebagai peluang sekaligus ancaman bagi bangsa yang bersifat multikultur. Studi pustaka adalah metode yang digunakan dalam penelitian ini. Landasan teoritis befokus pada teori hemogenitas budaya yang terjadi dalam masyrakat. Hasil penelitian membedakan secara garis besar tentang peluang dan ancaman globalisasi di bangsa Indonesia sebagai bangsa yang multi kultur. Peluang globalisasi disadari dengan munculnya rasa kolektifitas hidup bersama dalam perbedaan yang koeksistensi. Sedangkan ancaman yang muncul adalah menguatnya hemogenitas budaya ynag mampu mengikis nilai-nilai budaya lokal yang sudah tertanam sebelumnya. sehingga perlu adanya saran dan kesadaran yang tinggi dalam menyikapi dan merespon hemognitas budaya tersebut karena tidak tertutup kemungkinan bahwa akan adanya nilai yang bersifta destruktif dari globalisasi tersebut.

$\mathrm{Ni}$ Komang Ayu Astuti (2016) membuktikan dalam tulisannya bahwa peninggalan budaya, arkeologi, berperan penting dalam meningkatkan ketahanan budaya di Papua. Arus globalisasi membuat dunia semakin sempit. Kunjungan ke suatu negara dapat dilakukan dengan cepat dan mudah, oleh sebab itu pariwisata adalah alasan yang utama melakukan kunjungan ke negara lain. Arkeologi sebagai situs wisata dapat dijadikan objek yang bisa menarik pengunjung wisata. Di lain sisi, kunjungan wisata dapat memberikan dampak yang positif kepada masyarakat dan negara. Hasil penelitian ini menunjukkan bahwa mengoptimalkan sumber daya arkeologi di Papua dapat meningkatkan ketahanan ekonomibagi masyarakat. Selain itu, perlu adanya pelestarian situs budaya di Papua karena situs budaya itu ditemukan bervariasi dan mempunyai nilai yang unik dan bersifat kontekstual. Perbedaan itu yang akan menjadi potensi pasar terbukanya atraktif wisata di Papua.

Larasati (2018) mengkaji mengenai globalisasi budaya tentang pengaruh Hallyu (Korean wave) dan westernisasi di Indoensia. Eksistensi budaya dari barat sangat berakar di Indoneia. Namun eksistensi tersebut mendapat saingan yang cukup popular dengan adanya globalisasi atau modernisasi versi Asia dari Korea. Penelitian ini menggunakan konsep 3-H Scenarios yang menjelaskan tentang homegenisasi budaya, heterogenissi budaya, dan hibridisasi budaya. Hasil penelitain menunjukkan bahwa modernisasi negara barat mulai digeser dengan munculnya 
modernisasi dari Korea yang disebut "hallyu". Hal itu ditandai dengan minat masyarakat tentang simbol kebudayaan Korea meningkat seperti ketertarikan dalam hal seni, musik, makanan, fasion, make up, dan bahkan bahasa. alasan utama meningkatanya ketertarikan terhadap siombol tersbut karena persamaan wilyah dan budaya.

Dari penelitian di atas memberikan gambaran mengenai dampak globalisasi dan homogenisasi globalisasi budaya yang muncul sebagai hasil penetrasi budaya asing masuk ke dalam budaya lokal di beberap daerah di Indonesia. Namun penelitian ini akan memberikan gambaran mengenai globalisasi budaya di Jayapura-Papua khusunya mengenai budaya yang mencakup bahasa dan interracial marriage. Kedua bagian budaya ini adalah hal yang secara umum dapat dilihat dan dirasakan secara langsung terjadi dan berdampak di tengah perkembangan kota di Jayapura. Pemilihan unsur budaya itu karena didasarkan pada nilai kost dan benefit mengenai sikap dan selektivitas mahasiswa/i Indigenous People di Jayapura.

\section{METODE PENELITIAN}

Penelitian ini menggunakan metode deskripsi kualitatif. Metode ini memberikan deskripsi megenai keadaan yang berdasarkan fakta yang ada di lapangan dengan dukungan dari landasan teori terhadap data yang sudah dianalisa. Lambert (2012) menjelaskan bahwa tujuan dari studi deskripsi kualitatif adalah memberikan simpulan yang komprehesif dari setiap kejadian yang dialami oleh individu atau kelompok individu tertentu. Secara umum, penelitian ini bertempat di Jayapura dengan distribusi tempat yang berbeda-beda yaitu di asrma-asrama mahasiswa. Walaupun berbicara mengenai Papua tetapi kota Jayapura adalah kota yang bersifat melting pot yang menampung semua budaya baik dari dalam Papua dan budaya asing dari luar Papua. Budaya-budaya tersebut berjalan seiringan walupun mempunyai gap yang lumayan berbeda namun keunikan itu yang menjadi daya atraktif dalam penelitian ini.

\subsection{Prosedur Pengambilan Data}

Objek dari Penelitian ini adalah mahasiswa dan mahasiswi Papua yang melanjutkan pendidikan di Jayapura. Mereka berasal dari berbagai suku yang berada di Kabupatenkabupaten di Provinsi Papua. Tempat pengambilan data difokuskan pada asrama-asrama mahasiswa seperti asrama Biak, asrama Wamena, Asrama Fak-fak, dan asrama Merauke. Dalam mengambil data, teknik yang digunakan adalah teknik FGD (Focus Group Discussion). Teknik ini adalah teknik yang menggunakan diskusi kelompok terarah. Tidak ada batasan jumlah dalam setiap kali mengadakan FGD. Peneliti bertugas memandu jalannya diskusi, mengarahkan, menggali dan mengembangkan diskusi untuk mendapatkan inti dari setiap pertanyaan yang diinginkan. Ada dua bagian penting dari distribusi pertanyaan yang ada yaitu bahasa dan pernikahan antar ras di Jayapura. Mengenai bahasa pertanyaan didesain dengan kunci sejauh mana mereka berkontribusi terhadap bahasa yang (1) mengglobal yaitu bahasa asing termasuk bahasa Inggris, Korea, dan India, (2) bahasa nasional dan (3) bahasa lokal mereka. Sedangkan pertanyaan mengenai pernikahan silang didasari pada fokus pertanyaan yaitu sikap penerimaan dan pandangan mereka terhadap perilaku tersebut. Dalam jalannya diskusi, Peneliti merekam pembicaraan dan mendokumentasikan hasil rekaman tersebut dengan menggunakan alat rekam seperti handphone. Note taking juga diggunakan untuk mencatat hal-hal yang fundamental yang menyinggung rana kunci dari pertanyaan yang ada. Lama pengambilan data adalah 30 hari waktu kerja dan dilakukan secara terstruktur.

\subsection{Prosedur Analisis Data}

Pelaksanaan FGD adalah kunci dari pengambilan data dan kemudian data yang sudah dikumpulkan akan dianalisa dengan menggunakan tahapan (1) transkripsi data. Proses transkripsi data dilakukan dengan mengubah teks lisan dari hasil rekaman menjadi teks tulisan. Dalam mentranskrip data, peneliti memberi indeks coding pada responden dengan maksud tidak menyebut langsung nama dan asal dari responden tersebut. Kemudian peneliti melakukan tahapan (2) klasifikasi. Tahapan ini bertujuan untuk mereduksi data dengan cara mengklasifikasikan persamaan jawaban dari setiap responden. Sekaligus menyandingkan 
hasil transkrip dan hasil catatan lapangan. Klasifikasi juga didasarkan pada pola jenis kelamin dari masing-masing asrama sehingga dengan jelas dapat dibuktikan bahwa siapa yang mempunyai kesiapan dan kontribusi aktif, dari kedua jenis kalamin, dalam menghadapi globalisasi bahasa dan pernikahan antar ras di Jayapura. Selanjutnya, peneliti melakukan (3) penganalisisan data. Data dianalisa berdasarkan pada teknik terstruktur yaitu masalah dijawab berdasarkan pertanyaan yang diformulasikan yaitu mencari tahu bentuk penerimaan dan kontribusi mereka terhadap bahasa yang mengglobal du Jayapura dan sikap mereka sebagai indigenous people Papua melihat terjadinya pernikahan antar ras di Jayapura.

\section{HASIL DAN PEMBAHASAN}

\subsection{Hasil}

Di Jayapura terdapat paguyupan lokal Papua dalam bentuk asrama yang disediakan oleh pemerintah daerah. Tujuannya mempermudah putra-putri daerah ketika beranjak ke kota Jayapura dalam melanjutkan Pendidikan di Kota. Globalisasi budaya seperti bahasa, dan pernikahan antar ras tidak terelakkan ketika sudah ada di kota. Olehsebab itu berikut adalah klasifikasi data yang yang didasarkan pada gender/seks mengenai pandangan mahasiswa dan mahasiswi Papua setelah berada di Kota Jayapura. Selain itu, data juga disajikan mengenai peran aktif mereka terhadap pengembangan bahasa yang mereka alami ketika berada di kota Jayapura.

Tabel 1. Globalisasi Bahasa

\begin{tabular}{|c|c|c|}
\hline \multirow{2}{*}{ No } & \multicolumn{2}{|c|}{ Gender } \\
\hline & Laki-laki (Teks) & Perempuan (Teks) \\
\hline \multicolumn{3}{|c|}{ Bagaimana konteks Penggunaan Bahasa Indonesia di Jayapura? } \\
\hline 1 & $\begin{array}{l}\text { "Bahasa Indonesia kita gunakan setiap } \\
\text { hari”(AB01,AB02,AB03 dan AB07) }\end{array}$ & $\begin{array}{c}\text { "Kalau misalnya di asrama itu kita sering } \\
\text { pakai Bahasa nasional ,(AF01,AF03,AF06-12, } \\
\text { AW03,04,06,07, AB03,04,05,08-13) }\end{array}$ \\
\hline 2 & $\begin{array}{c}\text { "Berkomunikasi di kampus, Gereja dan } \\
\text { tempat umum lainnya }(A B 01-A B 02,03 \\
\text { dan } A B 07, A W 01,02,05,08, A M \\
01,02,07,-10)\end{array}$ & $\begin{array}{l}\text { “Umumnya di kampus di mall di sosial media } \\
\text { facebook dan WA (AB04,08,AF01,03,06, } \\
\text { AW03,04,07,09,10, AM08,10, dan 014)) }\end{array}$ \\
\hline 3 & $\begin{array}{c}\text { "Bahasa Indonesia sebagai bahasa } \\
\text { Nasional dan berlaku secara nasional } \\
\text { termasuk di Papua }(A B 01-13, \text { AW01- } \\
\text { 10,AM01-05,08, ) }\end{array}$ & $\begin{array}{l}\text { "bahasa Indonesia sebagai bahasa nasional } \\
\text { (AM08-14) }\end{array}$ \\
\hline 4 & $\begin{array}{c}\text { Mencampur bahasa Indonesia dan } \\
\text { bahasa lokal (hampir semua resoonden } \\
\text { di masing-masing asrama) }\end{array}$ & $\begin{array}{c}\text { "kami sering menggunakan bahasa campuran } \\
\text { tapi didominasi oleh bahasa Indonesia } \\
\text { (hampir semua mahasiswa perempuan di } \\
\text { amasing-masing asrama) }\end{array}$ \\
\hline \multicolumn{3}{|c|}{ Bagaimana Konteks Penggunaan Bahasa Lokal di Jayapura? } \\
\hline 1 & $\begin{array}{c}\text { Ketika menelfon ke keluarga di } \\
\text { kampung }(A B 01,07, A F 05,05, A W \\
01,02,05,08, A M 06,07)\end{array}$ & $\begin{array}{l}\text { Ketika bersama keluarga }(A B 04,08,13 \text {, } \\
\text { AF01,03,AW03,04,07,09,AM 08,dan 011) }\end{array}$ \\
\hline 2 & $\begin{array}{c}\text { Masih mengerti bahasa lokal } \\
(A B 01,03,07, A F 04,05, \\
A W 01,02,05,08, A M 08,10,13 \text {, dan } 14)\end{array}$ & $\begin{array}{c}\text { Mengerti bahasa lokal tapi susah untuk } \\
\text { merespond balik (AB05, } \\
\text { AF06,07,08,09,10,11,12, AW10, } \\
\text { AM09,10,12,13,14) }\end{array}$ \\
\hline 3 & $\begin{array}{c}\text { Sudah sangat jarang digunakan ketika } \\
\text { di kota (hampir semua mahasiswa laki- } \\
\text { laki di berbagai asrma) }\end{array}$ & $\begin{array}{l}\text { Sangat jarang digunakan di kota (Hampir } \\
\text { semua mahasiswi di berbagai asrama) }\end{array}$ \\
\hline 4 & $\begin{array}{c}\text { Sudah tidak menegerti bahasa lokal } \\
\text { (hampir semua mahasiswa masih } \\
\text { mengerti bahasa lokal) }\end{array}$ & $\begin{array}{c}\text { Sudah tidak mengerti bahasa lokal (hampir } \\
\text { semua mahasiwi mengerti degan kasus } \\
\text { sebagain tidak bisa merespon) }\end{array}$ \\
\hline \multicolumn{3}{|c|}{$\begin{array}{c}\text { Bagaimana Penggunaan Bahasa Asing di Jayapura, Inggris, Korea, India dan cara } \\
\text { pengakusisian bahasa tersebut? }\end{array}$} \\
\hline 1 & $\begin{array}{l}\text { Jarang digunakan karena tidak tahu } \\
\text { banyak (hampir semua mahasiswa di }\end{array}$ & $\begin{array}{l}\text { Penggunaannya terbatas (hampir semua } \\
\text { mahasiswi di asrama) }\end{array}$ \\
\hline
\end{tabular}




\begin{tabular}{|c|c|c|}
\hline & semua asrama) & \\
\hline 2 & $\begin{array}{c}\text { Diakusisi dari bahasa atau istilah yang } \\
\text { trend seperti "I love you, I need you } \\
\text { dan sebagainya } \\
(A B 01, A F 02, A W 05, A M 02)\end{array}$ & $\begin{array}{c}\text { Dibaca dari lebel-lebel tertentu dan didengar } \\
\text { dari TV dan yutube }(A B 04,05,12, A F 01,03, \\
\text { AW07,09, AM08,10) }\end{array}$ \\
\hline 3 & \multirow{2}{*}{$\begin{array}{c}\text { Kata/frase benda didapat dari tempat } \\
\text { umum seperti mall, supermarket, } \\
\text { beach, (AB01,AF02,AW05,AM02) }\end{array}$} & $\begin{array}{c}\text { Dicampur-campur dengan bahasa Indonesia } \\
(A B 04,05,12, A F 01,03, A W 07,09, A M 08,10)\end{array}$ \\
\hline 4 & & $\begin{array}{l}\text { Kata frase, kata umum seperti love, see, } \\
\text { beach, sea, market, campus, school dll } \\
(A B 04,05,12, A F 01,03, A W 07,09, \text { AM08,10) }\end{array}$ \\
\hline
\end{tabular}

Tabel 2. Globalisasi Interracial Marriage

\begin{tabular}{|c|c|c|}
\hline \multirow{2}{*}{ No } & \multicolumn{2}{|l|}{ Gender } \\
\hline & Laki-Laki (Teks) & Perempuan (Teks) \\
\hline \multicolumn{3}{|c|}{ Bagaimana Sikap Mengenai Pernikahan antar Ras di Jayapura? } \\
\hline 1 & $\begin{array}{l}\text { Setuju: Alasan sama-sama suka/cinta (hampir semua } \\
\text { mahasiswa setuju dengan alasan cinta) }\end{array}$ & $\begin{array}{l}\text { Setuju: Cinta yang menyatukan } \\
(A B 04, A F 06, A M 09)\end{array}$ \\
\hline 2 & $\begin{array}{lllll}\text { Setuju: perbaikan } & \text { keturunan } & \text { (AB07, } & \text { AF } & 05 \\
\text { AW07,AM06) } & & & & \end{array}$ & $\begin{array}{l}\text { Tidak setuju: alasan mempertahankan } \\
\text { ras (hampir semua mahasiswi } \\
\text { sependapat dengan hal ini) }\end{array}$ \\
\hline 3 & Tidak setuju: alasan tertentu (AF02) & \\
\hline \multicolumn{3}{|c|}{ Seringkah Terjadi di Daerah Anda? } \\
\hline & $\begin{array}{l}\text { Sangat jarang tetapi sudah ada beberapa } \\
\text { keluarga(hampir semua mahasiswa mengatakan di } \\
\text { asrma-asrama) }\end{array}$ & $\begin{array}{l}\text { Jarang karena adat melarang (hampir } \\
\text { semua mahasiswi mengatakan di } \\
\text { asrma-asrma) }\end{array}$ \\
\hline
\end{tabular}

\subsection{Pembahasan}

Pembahasan akan dibagi dalam dua bagian yaitu kontekstualisasi penggunaan dan eksistensi bahasa Kota Jayapura dan Pandangan Mengenai Inter-Racial Marriage yang sedang berlangsung secara melaus.

\subsubsection{Kontekstualisasi Penggunaan Bahasa di Jayapura}

Kunci dari pertanyaan bahasa hanya dirujuk pada kontekstualisasi dan eksistensi penggunaan bahasa di kota Jayapura. menurut Jimmi (2019) belajar bahasa erat hubungannya dengan masyarakat karena masyarakat berperan penting untuk mengembangkan dan menjaga bahasanya. Ada tiga bahasa yang yang ditekankan dalam pertanyaan yang terstruktur, yaitu bahasa nasional, bahasa lokal dan bahasa asing. Ditemukan bahwa baik mahasiswa dan mahasiswi Papua menafsirkan bahasa Indonesia adalah bahasa nasional yang bersifat umum dipakai di seluruh Indonesia. Dalam menjalin relasi sosial, bahasa Indoensia adalah bahasa yang berfaedah untuk saling mengerti intensi dari interlocutor yaitu pembicara dan pendengar. Inda Puspita Sari (2015) menguiraikan dalam penelitiannya bahwa bahasa Indonesia mempunyai kedudukan dan fungsi. Ia manambahkan lebih jauh bahwa kedudukan bahasa Indonesia yaitu sebagia bahasa nasional dan sebagai bahasa negara yang masing-masing diatur pada Sumpah Pemuda 1928 dan UUD 1945 pasal khusus (bab XV pasal 36).

Berdasarkan kedudukan di atas maka fungsi bahasa Indonesia yaitu sebagai lambang kebanggaan nasional, identitas nasional, alat penghubung atar warga, alat penyatuan berbagai suku dengan latar belakang sosial budaya yang berbeda. oleh sebab itu dapat disimpulkan bahwa bahasa Indonesia adalah alat pemersatu bangsa dari ragam bahasa dan budaya yang ada di Indonesia. Lagipula, sumpah pemuda pada tahun 1928 juga sebagai bukti bahwa bahasa Indoneisa adalah nyata sebagai alat pemersatu bangsa yang dari dulu sampai sekarang masih mempunyai power.

Selain itu setting penggunaan bahasa juga merupakan temuan pada penelitian ini. Setting adalah konteks tempat dan waktu menggunakan bahasa. Mahasiswa/i menjabarkan bahwa bahasa Indonesia digunakan di tempat umum seperti kampus, gereje, di dunia media sosial dan tempat-tempat lainnya. Ini membuktikan bahwa bahasa Indonesia sebagai bahasa nasional teraplikasi secara umum di kota Jayapura. Alat 
komunikasi tersebut dapat digunakan sebagai mediasi dalam transaksi, edukasi, negoisasi bahkan bahasa legal.

Yang unik dan menjadi fenomena bahasa adalah adanya istilah campur dan alih kode bahasa. mahasiswa/i Papua di Jayapura tidak jarang mengunakan 2 bahasa sekaligus. Mereka cenderung mencampur bahasa Indonesia dan bahasa lokal mereka. Pencampuran bahasa ini adalah fenomena bahasa yang berada pada kisaran sosiolinguistik yang disebut code mixing dan switching. Melihat konteks kejadian pada data temuan di atas maka kecenderungan yang terjadi adalah istilah campur kode atau code mixing dalam satu kalimat terjadi. Campur kode adalah percampuran dua bahasa dimana salah satu bahasa dominan dari bahasa yang lain. Pencampuran bahasa-bahasa tersebut baik dalam bentuk kata/frase maupun klausa yang tetap memperhatikan struktur susunan bahasa yang dominan. Sejalan dengan Ugot (2009:29) mendefisikan "Code mixing is usually the infusion of single words or items from the donor language into the L1 construction". Tidak ada Batasan mendalam mengenai campur dan alih kode. Bentahila and Davies (1983) mendefinisikan bahwa alih kode terkadang digunakan untuk meregister kemampuan menggunakan dua bahasa pada sitausi tertentu. Di sisi lain, campur kode didefenisikan sebagai pencampuran dua bahasa secara random pada satu kalimat.

Ketika seseorang menggunakan dua atau lebih bahasa maka orang itu disebut bilingual. Bilingual memperkenalkan istilah language choice yaitu bahasa yang sering dimotivasi dari faktor-faktor linguistic seperti Pendidikan, agama, ekonomi, kegiatankegiatan sosial budaya, politik dan pemerintahan, dan penggunaan lokal bahasa, (Ugot 2009).

Alasan pencampuran bahasa itu dapat disebabkan karena berbagai faktor. Salah satu faktor yang paling umum adalah karena pengguna bahasa tersebut mengenal dan mampu menggunakan kedua bahasa tersebut secara fasih baik dalm bentuk lisan dan tulisan. Dalam hal ini, campur kode adalah bukti yang menunjukkan bahwa pengguna kedua bahasa tersebut mempunyai status. Menurut Jimmi (2019) alasan camppur kode pada sosial media adalah untuk memberikan pengaruh pada pembaca dan penulis bahwa campur kode dapat memberikan bahasa yang bernilai untuk dikomunikasikan. Pada kasus bahasa lokal di Jaypura, Penggunaan bahasa lokal mereka sangat terbatas. Baik mahasiswa dan mahasiswi merasakan ruang lingkup yang kecil dalam menggunakan bahasa lokal. Mereka sebanarnya masih mengerti bahasa ibu mereka tapi aplikasi yang bersifat komunikatif sangat terbatas. Mereka mengakui bahwa bahasa lokal mereka digunakan ketika menelfon ke kampung (mahasiswa laki-laki dari responden $A B 01,07, A F 05,05, A W 01,02,05,08, A M 06,07)$ atau ketika mereka dapat kunjungan dari kerabat dan keluarga (mahasiswa perempuan dari responden $A B 04,08,13$, AF01,03,AW03,04,07,09,AM 08,dan 011). Selain itu kasus lain menunjukkan bahwa ada kegelisahan yang terjadi terhadap bahasa lokal mereka pada beberapa mahasiswi. Mereka mengalami kendala merespon balik walaupun mereka secara kognitif paham bahasa itu. Dilihat pada respoden (AB05, AF06,07,08,09,10,11,12,AW10,AM09,10,12,13,14) itu menunjukkan bahwa bahasa lokal mereka sedikit demi sedikit mengalami pergeseran. Ada faktor jangka pendek yang mengubah bahasa diantaranya adalah peran kota, perbedaan budaya yang menjolok, demografi, dan status (Gile 1977 dan Gradol 2004)

Akusisi bahasa asing bagi mahasiswa di Jayapura masih bersifat terbatas. Bahasa asing seperti bahasa Inggris, Korea, dan India hanya dinikmati dalam bentuk film yang mengglobal. Mahasiswa/i secara menyeluruh belum terkontaminasi akan bahasa asing tersebut. Namun demikian tidak tertutup kemungkinan bahwa bahasa asing seperti bahasa Inggris belum menjamur secara masif di Jayapura khususnya bagi indigenous people yang datang belajar di kota Jayapura. Bentuk-bentuk akusisi bahasa Inggris yang terjadi hanya terbatas dalam bentuk kata dan frase umum yang sering dilihat, dan dilakukan seperti supermarket, mall, beach, love, campus, school dll. Ini membuktkan bahwa cepat 
atau lambat bahasa Inggris akan mengambil peranan penting dalam penyebarannya di Jayapura. Bahasa Inggris adalah bahasa Internasional yang secara universal semua bangsa di dunia mengakui eksistensi dan kekuatan dari bahasa Inggris. Penyebaran bahasa Inggris dimulai dari bahan-bahan yang bersifat konkrit dan abstrak seperti bahan-bahan produksi, makanan, teknolgi dan pendidikan. Importensi dari bahasa Inggris adalah bahasa yang mempunyai status yang tinggi. Bahasa Inggris mengambil peran yang lebih luas dalam Pendidikan khususnya di universitas. Höglin dalam Estiliden (2017) berpendapat bahwa

"Some corporate groups have English as an official language although they may be based in Sweden. English is formally the official language for one third of the world's countries which is about 1, 5 billion people and at least 375 million people have English as their native language. The majority of international communication is done in English within important areas such as politics, marketing and the financial world (Höglin 2002, p.7)

Walaupun secara data bahwa akusis dan eksistensi bahasa Inggris bagi mahasiswa/i Papua di kota Jayapura masih bertaraf rendah namun secara official bahasa yang digunakan setiap harinya tanpa disadari mengandung bahasa Inggris yang banyak. Adanya bahasa serapan dan pinjaman dari bahasa Inggris kemudian dijadikan bahasa Indonesia adalah bukti dari kekuasaan dari bahasa Inggris. Haugen (1950) menjelaskan bahwa kata(leksikal) pinjaman adalah proses yang melibatkan mereproduksi bahasa tertentu kedalam suatu bahasa. Jadi bahasa/kata yang dipinjam adalah proses mendonor bahasa ke resiver bahasa yang melibatkan proses pada linguitik. Salah satu bentuk bahasa Indonesia yang dipinjam dari bahasa Inggris adalah bentuk derivasi/derivation yang secara morphology bahasa adalah bentuk yang menambahkan elemen kecil bahasa secara akhiran dan kemudian mengubah kelas kata tersebut. Sebagai contoh banyak kata dalam bahasa Indonesia, khususnya kata benda, yang berakhiran -si adalah serapan dari bahasa Inggris yang terkadang merupakan akhiran dari -tion. Proses derivasi dalam bahasa Inggris dan diadopsi kedalam bahasa Indonesia seperti information (inform menjadi information) menjadi informasi, komunikasi dari communicate communication) diadopsi kedalam bahasa Indonesia komunikasi. Daulton (2012), menambahkan bahwa kata pinjaman adalah kata yang diadopsi dalam bentuk kata tunggal maupun kelompok kata yang melibatkan bahasa dan dialek.

Akusisi bahasa asing di Jayapura tidak terjadi secara signifikan karena unsur industrialisasi. Maksudnya adalah penggunanaan bahasa Inggris di Jayapura belum meluas karena kota Jayapura masih dalam tahap berkembang sehingga serapan tenaga kerja yang siap dipekerjakan pada perusahaan dan industri yang mengutamakan bahasa Inggris belum menyebar secara meluas karana dipengaruhi oleh berbagai faktor. Selain itu, minat belajar bahasa dan sastra Inggris masih minim. Itu dapat dibuktikan di berbagai kampus yang mempunyai prodi sastra dan bahasa Inggris mahasiswanya masih minim dan didominasi oleh mahasiswa/I imigran non asli Papua.

Dari ketiga eksistensi dan kotekstual penggunaan bahasa tersebut di Jayapura, dapat disimpulkan bahwa bahasa yang mempunyai cost dan benefit yang paling umum digunakan adalah bahasa nasional. Cost yang pertama dapat dilihat dari arah pengguna bahasa kemudian didukung dari benefit yang berupa fungsi bahasa tersebut. Fungsi itu berupa alat pemersatu, peyambung ide/gagasan pada suku bangsa yang berbeda dan sebagai alat bersosialisasi dengan masyarakat sekitar. Ruang lingkup juga membentuk bahasa itu berharga/cost. Kasus bahasa lokal Papua jarang digunakan di Papua karena konteks tempat dan waktu yang tidak mendukung. Sehingga benefit menggunakan bahasa lokal di kota Jayapura tidak berefek. Jadi kota dan perkembangannya bisa atau potensial mengubah dan menggesar bahasa lokal yang eksis di Jayapura.

Salah satu kebijakan dari Kemendikbud adalah mengiijinkan balai bahasa masingmasing provinsi untuk mengetahui 3 bahasa sekaligus dengan porsi yang berbeda. Porsi itu adalah merujuk kepada utamakan bahasa Indonesia, lesatrikan bahasa daerah, dan 
kuasai bahasa Asing. Itu menandakan bahwa bahasa adalah alat fundamental yang bisa membawa dan menambah karakter bangsa Indonesia.

\subsubsection{Respond terhadap Inter-Racial Marriage}

Bertolak pada data pusat statistik tahun 2010 (dalam Pramudito 2017) memebuktikan bahwa pernikahan antar ras dan budaya yang berbeda relatif tinggi. Cara menarik kesimpulan dengan melihat adanya perpindahan penduduk yang bersifat permanen yang memungkinkan sudah melakukan perkawinan antar budaya. Secara khusus di Papua ada dua sikap yang muncul yang berupa tanggapan mahasiswa indigenous people mengenai pernikahan antar ras yang sementara terjadi dan terusmenerus terjadi di kota jayapura. Respon tersebut berupa kesiapan yang mengimplimentasikan dan ketidak siapan menghadapi perpaduan dua etnis dan budaya yang berbeda. Laki-laki cenderung menerima kasus pernikahan antar ras di Jayapura. mereka beranggapan bahwa pernikahan semacam itu adalah pernikahan yang terjadi secara alamiah dan wajar karena merupakan rasa cinta. Alasan lain yang mendukung mereka terbuka denga pernikahan antar ras adalah perubahan keturunan. Di lain sisi perempuan menentukan sikap bahwa pernikahan antar ras adalah pernikahan yang seharusnya tidak terjadi karena alasan ketahanan dan kepunahan ras asli. Mereka cenderung memperthankan keaslian ras mereka. Lagipula adat mereka cenderung mengikat bahwa mereka harus menikahi sesama ras/dan sesama suku.

Memang jika ditinjau pada peneliti yang melakukan penilitian sebelumnya mengenai pernikahan antar ras. Mereka cenderung memaparkan bahwa pernikahan beda ras adalah sarat dengan konflik. Sebagi contoh, Apriani dan Fauziah (2013) menemukan bahwa permasalahan perkawinan antar budaya Jawa dan Tionhoa terletak pada prasangka bahwa wanita Jawa adalah pemalas sehingga cara mengatasi adalah wanita harus membantu suaminya bekerja. Penemuan ini menunjukkan bahwa wanita harus berada pada kendali laki, Tinghoa, sehingga wanita lebih sempit ruang lingkupnya untuk megembangkan karir yang mereka inginkan. Ada beberpa faktor yang menyebabkan sering terjadinya konflik pada pernikahan antar ras. Cara pandang yang berbeda cenderung menciptakan konflik. Letiecq (2007) memeberikan contoh bahwa cara pandang istri yang menikah dengan beda budaya selalu berpandangan tidak adil dalam pernikahan karena cara pandang yang bersifat egaliter. Selain itu faktor kognitif juag menentukan tingkat kematangan dalam pernikahan beda budaya dan ras karena kognisi mencakup tingkat mental yang merangsang indera menjadi masukan yang bersifat tahu dan paham. Pramudito (2017) menambahkan bahwa pernikahan antar ras perlu membutuhkan adaptasi dari masing-masing pasangan. Selain itu dia manabahkan bahwa adapatsi dilakukan untuk meminilisir konflik-konflik yang sering terjadi. Serta perlunya model kompromi dan integrasi untuk mencegah konflik baru karena beda budaya.

Dapat disimpulkan bahwa penolakan atau sikap tertutup mahasiswi Indigenous People Papua mengenai pernikahan antar rasa atau inter-racial marriage yang melibatkan dua suku berbeda berada faktor internal yaitu dorongan ketidak siapan menghadapi konflik yang terjadi karena prasangka yang bersifat steriotip, perbedaan pandangan dan perbedaan kognitif. Selain itu respond penutupan diri juga disari pada faktor eksternal yang berupa adanya larangan dari suku masing demi melestarikan ras mereka yang hampir punah.

\section{KESIMPULAN}

Kota Jayapura merupakan ibukota provinsi Papua yang mengalami perubahan yang cukup pesat. Arus mobilisasi penduduk ke Jayapura yang dilatar belakangi pada faktor transmigrasi dan nilai ekonomis membuat kota ini semakin ragam rupa dan budayanya. Selain itu arus perkembangan kota tidak kalah pentingnya yang membuat globalisasi budaya semakin mewabah. Mahasiswa indigenous people Papua secara langsung terlibat langsung dalam proses globalisasi budaya yang terjadi di Papua. Eksistensi dan perubahan penggunaan bahasa yang 
meliputi bahasa lokal, nasional dan asing adalah wujud merambahnya globalisasi budaya di kota Jayapura. Mereka menyadari adanya ruang lingkup yang kecil menggunakan bahasa lokal mereka sehingga yang memungkinkan terjadi adalah adanya fenomena bahasa yang mewajibkan pengguna bahasa tersebut harus mengaplikasi bahasa yang mempunyai benefit tertentu. Language choice pada aspek code mixing adalah salah satu alternatif bahasa yang mereka gunakan untuk menjalin relasi secara sosial. selain itu, pernikahan antar ras yang berbeda juga semakin teras dan terus terjadi di Papua. Tidak hanya pernikahan antara ras Papua, sebagai ras malenesia, yang mengalami pernikahan dengan ras lain tetapi juga ras-ras lain yang berada di Jayapura ikut terlibat dalam bentuk pernikan tersebut. adanya penerimaan dan penolakan karena berlandaskan faktor yang bersifat internal dan eksternal.

\section{SARAN}

Penelitian ini mengharapkan supaya adanya sandingan penelitian selanjutnya yang melengkapi penelitian ini yang mengkaji globalisasi budaya di Jayapura yang dilihat dari sudut pandang tertentu seperti pola hidup, religi, style dll.

\section{DAFTAR PUSTAKA}

Apriani, N., Sakti, H., dan Fauziah, N. (2013). Penyesuaian Diri Wanita Etnis Jawa yang Menikah dengan Pria tnis Cina. Empati, 2(4), 305-315.

Bentahila, A.Y and Davies E, Eirlys. (1983). The syntax of Arabic French code- switching. Lingua Amsterdam. 59:301- 330.

Imanda, D. A dan Masykur, A. M. (2016). Menjalani Pernikahan antar Ras (Studi Kualitatif Fenomenologis pada Wanita Pelaku Interracial Marriage). Jurnal Empati, Volume 5(2), 378384.

Daulton, F. E. (2012). Lexical Borrowing. Online Library: https://doi.org/10.1002/9781405198431.wbeal0687.

Donny Ermawan T. 2017. Pengaruh Globalisasi terhadap Eksistensi Kebudayaan Daerah di Indonesia. Jurnal Kajian LEMHANNAS RI. Edisi 32. Hal 5-11.

Giddens, Anthony. 2001. Runway World; Bagaimana Globalisasi Merombak Kehidupan Kita?. PT. Gramedia Pustaka Utama, Jakarta.

Graddol, D. 2004. The Future of Language. A journal of Science 303, 1329-1331. (doi:10.1126/scince.1096549.

Estliden, K.P. (2017). A Study of Attitudes and Motivation towards English and English language Learning in Swedish Upper Secondary School. A thesis, Akademin for Utbildning OCH Ekonomi, Avdelningen for Humaniora. Available in https://www.divaportal.org/smash/get/diva2:1078032/FULLTEXT01.pdf

Giles, H. Language, Ethnicity, and Intergroup Relations. New York: Academic Press, 1987.

Hanifa, Winda. Sturuktur Internal Kota Semarang. Tesis, Program Magister Perencanaan Wilayah dan Kota, ITB. Tersedia pada laman https://www.academia.edu/38693726/STRUKTUR_INTERNAL_KOTA_SEMARANG

Haugen, E. (1950). The Analysis of Linguistic Borrowing. Linguistic Society of America, Vol.26, No.2, 210-231.

Indah Puspita Sari. (2015). Pentingnya Pemahaman Kedudukan dan Fungsi Bahasa Indonesia Sebagai Pemersatu Negara Kesatuan Republik Indonesia (NKRI). Prosiding Seminar Nasional Bulan Bahasa UNIB 2015.

Indriyani, D dan Agustinah, S.Wulan. (2019). Dampak Globalisasi terhadap Perilaku Belajar Siswa di SMK Negeri 1 Cianjur. Jurnal E-Issn - 53-61.

Jimmi and Davistasya (2019). Code-Mixing in Language Style of South Jakarta Community Indonesia. PJEE, Premise Journal of English Education and Applied Linguistics, Vol. 8 No 2, October 2019, e-ISSN: 2442-482x, p-ISSN: 2089-3345, p.193-213. Available in https://fkip.ummetro.ac.id/journal/index.php/english

Lambert, V.A., and Lambert, C.E. (2012) Qualitative Descriptive Research: An Acceptable Design. Pacific Rim International Journal of Nursing Research, 16(4). 255-256. 
Larasati, Dinda.( 2018). Globalisasi Budaya dan Identitas: Pengaruh dan Eksistensi Hallyu (KoreanWave) Versus Westernisasi di Indonesia. Jurnal Hubungan Internasional, Tahun XI, No.1, Januari - Juni 2018.

Ugot, Mercy. (2010). Language Choice, Code-Switching and Codemixing in Biase. global Journal of Humanities ISSN 1118-0579, Vol 8, No. 2, 2010: 27-35.

Ni Komang Ayu Astiti. (2018). Mengoptimalkan Sumber Daya Arkeologi Sebagai Daya Tarik Wisata untuk Ketahanan Budaya (Studi Kasus Sumber Daya Arkeologi di Provinsi Papua). Jurnal Papua, Volume 8, No.2, November 2016: 161-178.

Pramudito, A. Agung. 2017. Merenda Cinta Melintas Budaya Hingga Senja Tiba (Studi Literatur tentang Perkawinan Antar-Budaya). Buletin Psikologi. ISSN 0854-7106 (Print), ISSN 2528-5858 (Online) Vol. 25, No. 2, 76 - 88. DOI: 10.22146/buletinpsikologi.27233. Tersedia di https://jurnal.ugm.ac.id/buletinpsikologi

Rendell. 2010. Why Copy Others? Insight from the Social Learning Strategies Tournamnet. AAAS New York Washington.

Sholahuddin, Umar. (2019). Globalisasi: Antara Peluang dan Ancaman bagi Masyarakat Multikultural Indonesia. Jurnal Sosiologi Pendidikan Humanis, P-ISSN 2502-7875 E-ISSN 2527-5879, Vol. 4 No. 2 Dsember 2019.

Surahman, Sigit. 2013. Dampak Globalisasi Media terhadap Seni dan Budaya Indonesia. Jurnal Komunikasi, Volume 2, Nomor 1, Jan - April 2013, halaman 29 - 38.

Uno, Hamzah B., dan Lamatenggo, Nina. (2014). Teknologi Komunikasi dan Informasi Pembelajaran. Jakarta: PT. Bumi Aksara.

Wahyuni, R. B dan Banowati, E.E. (2016). Gaya Hidup Remaja Kelas Menengah Kota Pekalongan. Journal of Educational Social Studies (JESS) p-ISSN 2253-6390, e-ISSN 2502-4442 Vol 5 (2) 97-103.

Yulianto, Vissia Ita. (2007). Pesona Barat di Indonesia. Yogyakarta: Penerbit JALASUTRA. 